\title{
Avoiding Issue Preclusion by Settlement Conditioned upon the Vacatur of Entered Judgments
}

\author{
William D. Zeller
}

Issue preclusion ${ }^{1}$ prevents the relitigation of issues actually and necessarily determined by a valid and final judgment. ${ }^{2} \mathrm{~A}$ party against whom an issue has been conclusively determined in one suit may be precluded from relitigating the issue against a third party in another action. ${ }^{3}$ Under an adversary system which produces many independent claims containing identical issues, ${ }^{4}$ rules of issue preclusion achieve a compromise between party autonomy and the judicial values of finality of judgments, economy, legitimacy, and consistency. ${ }^{\circ}$

These judicial values are undermined when parties to an action agree to settle on condition that the entered judgment be vacated. Indeed, the very purpose of settlement conditioned on vacatur is to avoid future issue preclusion. Settlement conditioned on vacatur, moreover, may soon become a standard practice: Third-party issue preclusion has wide applicability, ${ }^{\circ}$

1. Issue preclusion is also known as collateral estoppel. F. James \& G. HazArd, Civin ProceDURE $§ 11.16$ (3d ed. 1985) [hereinafter JAMES \& HAZARD]. Claim preclusion, the doctrine of merger and bar, prevents relitigation of a later action on a previously determined claim. Id. $\S 11.3$. Issue preclusion and claim preclusion together compose the concept of "res judicata." Id.

2. Restatement (SeCOND) of Judgments $§ 27$ (1980) [hereinafter Restatement]. Relitigation of an issue is precluded at the discretion of the court in which issue preclusion is invoked. See id. $\S \S 28-29$; infra notes $80,90-95$, and accompanying text.

3. This Note is concerned only with third-party, or nonmutual, issue preclusion. Traditionally, the mutuality rule restricted issue preclusion to the original parties and those in privity. See, e.g., Bigelow v. Old Dominion Copper Mining \& Smelting Co., 225 U.S. 111, 126-29 (1912). "Under the limiting constraint of mutuality, a party in a later action cannot demand preclusion of an issue on the basis of an earlier lawsuit unless he or she would also have been precluded by a contrary judgment in the earlier suit." George, Sweet Uses of Adversity: Parklane Hosiery and the Collateral Class Action, 32 Stan. L. Rev. 655, 655 (1980) (footnotes omitted). Beginning with Bernhard v. Bank of America National Trust \& Savings Association, 19 Cal. 2d 807, 122 P.2d 892 (1942), the mutuality rule has been widely repudiated. JAMES \& HAzARD, supra note $1, \S 11.24$.

4. Consider the example of a train accident in which 50 passengers from several states suffer injuries. Each passenger files a separate personal injury claim against the railroad. Rules of jurisdiction allow plaintiffs to bring suit in several different state and federal courts. Even if all $\mathbf{5 0}$ plaintiffs initiate suit in one court, universal joinder is unlikely. See Currie, Mutuality of Collateral Estoppel: Limits of the Bernhard Doctrine, 9 STAN. L. Rev. 281, 281 (1957).

5. See generally JAMES \& HAZARD, supra note $1, \S 11.2$ (policy considerations underlying res judicata). For a discussion of these private and public interests, see infra notes 41-42, 47-52, and accompanying text.

6. See, e.g., Schroeder, Relitigation of Common Issues: The Failure of Nonparty Preclusion and an Alternative Proposal, 67 IowA L. REv. 917, 917 (1982) ("potential for repetitive adjudication of 
and both parties to an action may have incentives to settle so as to eliminate continuing preclusive effect. ${ }^{7}$

To preserve the balance among private and public interests embodied in rules of third-party preclusion, standards must be formulated which constrain the use of settlement conditioned on vacatur. ${ }^{8}$ Clear standards are necessary to ameliorate problems of joinder and unfairness. This Note argues that settlement conditioned on vacatur should be (1) prohibited in cases giving rise to the possibility of issue preclusion against a common plaintiff, and (2) left largely to trial court discretion in cases which may serve as a basis for preclusion against a common defendant.

\section{The Problem of Settlement Gonditioned on Vacatur}

\section{A. The Nestle Cases}

Nestle Co. v. Chester's Market, Inc. ${ }^{9}$ illustrates the factual underpinnings of the problem of settlement conditioned upon vacatur. Nestle, owner of five trademarks for "Toll House," sued Saccone's Toll House for trademark infringement and unfair competition. ${ }^{10}$ The district court granted Saccone's motion for partial summary judgment on the infringement claim, on the grounds that "Toll House" is a generic name when applied to cookies. ${ }^{11}$ Final judgment was entered in favor of defendant Saccone. At that time, a defendant in a separate suit against plaintiff Nestle could have invoked the judgment to preclude Nestle from relitigating issues conclusively determined in favor of Saccone. ${ }^{12}$

Nestle filed a notice of appeal while pursuing settlement negotiations with Saccone. The parties agreed to settle not only the trademark infringement claim, but also Nestle's remaining claims against Saccone; however, they conditioned this settlement upon the district court's vacatur of the entered judgment. ${ }^{13}$

The district court refused to vacate the judgment. The court, holding

issues is an inherent aspect of our adversary system").

7. See infra note 56.

8. An in-depth exploration of the doctrine of issue preclusion is beyond the scope of this Note. However, the expanding scope of issue preclusion, see supra note 3 ; infra text accompanying notes 75,81 , indicates that the doctrine serves important purposes in our procedural system. When litigants attempt to modify rules of preclusion by contract (the agreement to settle conditioned on vacatur), their actions should be evaluated by the criteria upon which issue preclusion stands.

9. 596 F. Supp. 1445 (D. Conn. 1984) (joint motion to vacate), rev'd, 756 F.2d 280 (2d Cir. 1985).

10. Nestle, 571 F. Supp. 763 (D. Conn. 1983) (adjudicating merits of Nestle's trademark infringement claim).

11. Id. at 766-68.

12. See 1B J. MoOre, J. Lucas \& T. Currier, Moore's Federal Practice II 0.416[3] (2d ed. 1984) [hereinafter J. MOORE] (in federal courts, neither possibility nor pendency of appeal suspends preclusive effect of otherwise final judgment).

13. Nestle, 596 F. Supp. at 1446. 
that the question of vacatur was within its discretion, ${ }^{14}$ explored standards to guide this discretion. The district court emphasized the "overriding" judicial and public interest in finality of judgments. ${ }^{15}$ In fact, it suggested that the judicial preference for finality is so strong that Nestle might be precluded from relitigating adversely determined issues even if the judgment were vacated. ${ }^{16}$ Accordingly, the court held that the judicial interest in finality outweighed the parties' desire to avoid further litigation. ${ }^{17}$

The court of appeals reversed, holding that the district court abused its discretion. ${ }^{18}$ The appellate court asserted that "policies favoring finality of judgments are intended to conserve judicial and private resources."10 Refusing to vacate would have been "counterproductive"; $; 0$ it would have led to more litigation and forced defendant Saccone "to bear the costs and risks of further litigation."21 Preferring settlements that moot the controversy over finality, ${ }^{22}$ the court granted the parties' motion to vacate. The Nestle decision leaves unclear when, if ever, the parties' interests may be subordinated by a refusal to vacate.

\section{B. Preclusive Effect of the Vacated Judgment}

In Nestle, the court of appeals held only that the entered judgment had to be vacated to allow the parties' settlement agreement to take effect. The opinion is silent about the consequences of vacatur in future proceedings; a judge in a later suit might choose to recognize the preclusive effect of the initial judgment despite its vacatur.

Ordinarily, vacated judgments do not support issue preclusion ${ }^{23}$ in later

14. Id. at 1450. In considering whether it had discretion to vacate, the district court first held that the proposed settlement did not moot the controversy. Id. at 1448-49. Treating the parties' request as a motion for relief from judgment under FED. R. Crv. P. 60(b), it then determined that the Federal Rules did not require that the motion be granted. Nestle, 596 F. Supp. at 1449-50.

15. Nestle, 596 F. Supp. at 1451.

16. Id. at 1453 (citing Chemetron Corp. v. Business Funds, Inc., 682 F.2d 1149 (5th Cir. 1982), cert. denied, 460 U.S. 1013 (1983)); see infra note 25.

17. Nestle, 596 F. Supp. at 1455. The district court, probing in dicta the policy outcomes of vacating the judgment of trademark invalidity, focused on Nestle's potential unfairly to threaten suit against other defendants. Id. at 1454-55.

18. Nestle, 756 F.2d 280, 284 (2d Cir. 1985).

19. Id. at 282 .

20. Id.

21. Id. at 284 .

22. Id. at 283 .

23. It is unclear whether settlement conditioned on vacatur destroys the precedential value of the trial court's opinion. Normally, vacating a judgment as moot deprives the accompanying opinion of precedential effect. See County of Los Angeles v. Davis, 440 U.S. 625, 634 n.6 (1979). But see id. at 646 n.10 (Powell, J., dissenting) ("expressions of the court below on the merits, if not reversed, will continue to have precedential weight"); 13A C. Wright, A. Miller \& E. CoOpER, Federal PracTICE AND PROCEDURE $\$ 3533.10$ (2d ed. 1984) [hereinafter WRIGHT, MILLER \& COOPER] (criticizing rule because such opinions have been "tested in the same crucible as all opinions"). In the context of settlement conditioned on vacatur, however, judgment is not vacated for mootness. See infra notes 31-33 and accompanying text. 
suits. ${ }^{24}$ However, courts have suggested that settlement conditioned upon vacatur of an entered judgment does not reduce the preclusive effect of the judgment. ${ }^{25}$ At present, the continuing preclusive effect of final judgments vacated pursuant to settlement agreements remains uncertain. ${ }^{28}$

Vacated judgments should carry no preclusive effect. A rule permitting

Regardless of how settlement conditioned on vacatur affects the precedential weight of an opinion, the opinion continues to provide some benefits to society. Published opinions remain in the official reporters despite vacatur of the underlying judgments, see Retail Stores Employees Union v. NLRB, 85 Lab. Cas. (CCH) I 10,993 (D.C. Cir. 1978) (Robinson, C.J., dissenting) (arguing that court bound by own precedent even though Supreme Court vacated underlying judgment for mootness); these opinions continue to guide private decisionmaking, see Brunet, Measuring the Costs of Civil Justice, 83 Mich. L. REv. 916, 933 (1985) ("case law [has] immense societal value" because it guides non-litigants); Chayes, The Role of the Judge in Public Law Litigation, 89 Harv. L. Rev. 1281, 1285 (1976) (litigation seen as guiding future private actions).

24. See Dodrill v. Ludt, 764 F.2d 442, 444 (6th Cir. 1985); Universal Gity Studios, Inc. v. Nintendo Co., 578 F. Supp. 911, 919 (S.D.N.Y. 1983), affd, 746 F.2d 112 (2d Cir. 1984); Angstrohm Precision, Inc. v. Vishay Intertechnology, Inc., 567 F. Supp. 537, 540 (E.D.N.Y. 1982). Preclusive effect is destroyed whether a trial court or appellate court vacates the judgment. J. MoorE, supra note 12, \$0.416[2].

25. The district court raised this possibility in Nestle: "The interest in preventing needless relitigation is so strong that Nestle might find itself precluded from again testing the validity of the Toll House trademark even if this motion [to vacate] were to be granted." 596 F. Supp. at 1453. This remark goes against the grain of the opinion; elsewhere, the court stated that if judgment were vacated, Nestle would be able to relitigate the validity of the Toll House trademark. Id. at 1452. The appellate court did not consider the preclusive effect of the vacated Nestle judgment. 756 F.2d 280; see also Angstrohm Precision, 567 F. Supp. at 540-41 (in dicta, court expressed uncertainty about whether settlement conditioned on vacatur would destroy continuing preclusive effect); Note, The Impact of Collateral Estoppel on Postjudgment Settlements, 15 Sw. U.L. REv. 343, 353, 368 (1985) [hereinafter Note, Postjudgment Settlements] (application of issue preclusion justified where party settled first action to escape preclusive effect).

26. No court has applied issue preclusion despite prior settlement conditioned on vacatur. One court, however, has applied preclusion where the initial trial court's findings of fact and conclusions of law had been withdrawn-before entry of judgment-as a condition of settlement. See Chemetron Corp. v. Business Funds, Inc., 682 F.2d 1149, 1187-92 (5th Cir. 1982), cert. denied sub nom. Bintliff v. Chemetron Corp., 460 U.S. 1013 (1983). (The Supreme Court granted certiorari to consider a separate appeal. See Chemetron Corp. v. Business Funds, Inc., 460 U.S. 1007 (1983) (vacating and remanding).) The Chemetron court's reasoning is questionable.

The Chemetron court asserted that the prior action had attained the level of finality required for preclusion. In thus preventing relitigation of issues contained in the withdrawn determination, the court brushed aside possible challenges by claiming that Parklane Hosiery Co. v. Shore, 439 U.S. 322 (1979) (allowing third-party plaintiffs to invoke issue preclusion against defendant who lost prior judgment), "created a "need to redefine the doctrine of [issue preclusion]." "Chemetron, 682 F.2d at 1190 (quoting Migues v. Fibreboard Corp., 662 F.2d 1182, 1187 (5th Cir. 1981)).

Chemetron's focus on finality is misplaced. There is no question that a judgment vacated pursuant to settlement is "final," just as a reversed judgment is final. However, if a judgment is vacated, for whatever reason, it should not carry preclusive effect. See cases cited supra note 24 . Specifically, "if the parties to a suit enter into an extrajudicial settlement or compromise, there is no judgment, and future litigation is not barred by [issue preclusion]." Kaspar Wire Works, Inc. v. Leco Eng'g \& Mach., Inc., 575 F.2d 530, 538 (5th Cir. 1978) (footnote omitted). Furthermore, if the court in the initial action had wished to preserve preclusive effect, it would have dismissed rather than vacated. Vacatur clears the way for future relitigation; dismissal allows application of res judicata. See United States v. Munsingwear, Inc., 340 U.S. 36 (1950). "Upon this decision [to vacate or to dismiss] may turn the future res judicata effects of the district court's judgment." Wirtz v. International Union of Operating Eng'rs, 366 F.2d 438, 442 (2d Cir. 1966) (citing Munsingwear, 340 U.S. 36). In applying preclusion on the basis of a vacated judgment, a second court overrides the initial court's decision to permit relitigation of issues. 
a second forum to preclude relitigation of issues contained in a vacated judgment would reduce settlement conditioned on vacatur to simple settlement. Given that settlement to avoid continuing preclusive effect should be allowed in some cases, ${ }^{27}$ allowing a second court to circumvent the initial court's decision to vacate undermines judicial fairness, certainty, economy, and consistency. ${ }^{28}$

\section{Mootness}

In Nestle, the parties argued that their settlement conditioned upon vacatur eliminated the controversy and therefore mooted the case. ${ }^{20}$ If this argument were correct, trial courts would have no discretion to deny the parties' motion to vacate.

Mootness presumes "the absence of a definite and concrete controversy." 30 Both Nestle opinions, however, correctly state that a controversy remains alive despite a joint motion to vacate; ${ }^{31}$ the parties carefully preserved their rights to appeal and prepared to press other pending claims. ${ }^{32}$

27. See infra Section III.C.2.

28. Assume that two parties successfully institute settlement conditioned on vacatur, with the expectation that the party which lost the trial will be free to relitigate any issues in future suits. A subsequent forum then applies preclusion despite vacatur. The two forums have reached inconsistent conclusions. The losing party is penalized for negotiating a settlement and foregoing its appeal in reliance upon the first determination. Inconsistency creates wide-ranging and unwarranted uncertainty. Judicial resources are wasted when two courts rule separately on an identical legal question. Finally, a third co"rt may still allow relitigation of the issue in question and thus create further inconsistency.

In Ringsby Truck Lines v. Western Conference of Teamsters, 686 F.2d 720, 722 (9th Cir. 1982), the court addressed the problem of settlement conditioned on vacatur in dicta, asserting that the preclusive effect of the entered judgment should be decided by either the first forum or the forum where preclusion is asserted. This assertion is consistent with the position taken in this Note. The first forum makes the final decision if it vacates, because vacatur prevents the future assertion of issue preclusion. If the initial court refuses to vacate, the second forum has discretion to allow relitigation of issues decided in the first action.

29. Nestle and Saccone argued that (1) their settlement agreement mooted the controversy, Memorandum in Support of the Joint Motion of the Parties at 5-6, Nestle Co. v. Chester's Market, Inc., 756 F.2d 280 (2d Cir. 1985) (No. 83-7753), and (2) when a case has become moot pending appeal, the appellate court must vacate to deprive the judgment of future preclusive effect, id. at 6-29; (3) therefore, the court was required to vacate the judgment of the district court in order to trigger operation of the settlement agreement, $i d$. at 8,30 .

The second premise of this argument is a correct statement of the Munsingwear rule, see United States v. Munsingwear, Inc., 340 U.S. 36 (1950). However, under this rule, courts must vacate judgments where outside circumstances render the controversy moot, not where the parties deliberately moot their controversy. See Center for Science in the Pub. Interest v. Regan, 727 F.2d 1161, 1165-66 (D.C. Cir. 1984); Wisconsin v. Baker, 698 F.2d 1323, 1330-31 (7th Cir.), cert. denied, 463 U.S. 1207 (1983); Ringsby, 686 F.2d at 722 (where parties settled and therefore were responsible for rendering case moot, correct rule was to dismiss as moot while refusing to vacate).

30. Nestle, 596 F. Supp. at 1448 (stating "hornbook law") (citing Aetna Life Ins. Co. v. Haworth, 300 U.S. 227 (1937)).

31. "[The Munsingwear] rule is inapplicable in the present case because it is not moot." Nestle, 756 F.2d at 281; see Nestle, 596 F. Supp. at 1448-49.

32. Nestle, 596 F. Supp. at 1448. The very conditionality of the settlement agreement demonstrated controversy. See Nestle, 756 F.2d at 281-82. 
The mootness argument reduces to a circularity: The trial court must act to moot the controversy because the controversy is already moot. ${ }^{33}$ Thus, merely proposing settlement conditioned upon the vacatur of an entered judgment does not moot the controversy.

The foregoing analysis demonstrates that the effect of vacatur should be decided at the time of vacatur, and that vacatur is not automatic because the controversy is not mooted by settlement conditioned on vacatur. Thus, courts must decide whether to effectuate settlement by vacating an entered judgment. This Note proposes standards to guide this decision.

\section{Competing Absolute Standards}

In deciding Nestle, the court of appeals and the district court found very little ground for agreement. The courts seemed to argue for, respectively, always vacating to allow settlement, ${ }^{34}$ or always refusing to vacate. ${ }^{35}$

Indeed, the Nestle opinions exemplify two opposing conceptions of the role of adjudication in society. ${ }^{86}$ According to one view, each court must strive for individual justice as between the parties before it; reaching

33. Under United States v. Munsingwear, Inc., 340 U.S. 36 (1950), vacatur is the consequence of mootness. See supra note 26 . Where settlement is conditional, mootness is the consequence of vacatur. Nestle, 756 F.2d at 282.

34. The court of appeals held that the district court abused its discretion by refusing to vacate. 756 F.2d at 284 . However, the opinion is written in such a way that it is difficult to conceive of a situation where refusing to vacate would be permissible. The appellate court argued that (1) where settlement terminates pending litigation, the district court must vacate, id. at 282-83; (2) settlements are to be honored over the finality imposed by issue preclusion, id. at 283 ; and (3) there is no justification for forcing the party not fearing preclusion to bear the costs and risks of further litigation, id. at 284. All of the foregoing bases of the court's decision will be present in every situation where settlement conditioned on vacatur is proposed.

35. According to the district court, "[t]he interest in finality is sufficiently overriding that res judicata applies even when it leads to harsh results"; this interest outweighs " any individual judge's ad hoc determination." " Nestle, 596 F. Supp. at 1451 (quoting Federated Dep't Stores, Inc. v. Moitic, 452 U.S. 394, 401 (1981)). Although the district court also discussed policy concerns unique to the substantive law at issue, it stated that general finality considerations, standing alone, were sufficient to require denial of the motion to vacate. Nestle, $596 \mathrm{~F}$. Supp. at 1453.

36. The standards at the heart of the district court's opinion include finality of judgments, efficient allocation of resources, judicial economy, consistency, public respect for the courts, and efficacy of trademark regulation. Nestle, 596 F. Supp. at 1451-55. These are essentially public interests. Conversely, the appellate court concentrated on private interests: autonomy of parties, preference for settlement, and conservation of private resources. Nestle, 756 F.2d at 282-84. 
broader societal goals is incidental. ${ }^{37}$ The competing view emphasizes societal justice rather than individual justice. ${ }^{38}$

Private and public interests coexist as separate preferences in our jurisprudence. It is often assumed that such interests may be pursued simultaneously to reach a uniformly just result. ${ }^{39}$ However, settlement conditioned on vacatur by opposing parties who conspire to evade future preclusive effects draws private and public goals into confrontation. ${ }^{40}$ To favor one set of interests is to diminish the other, but neither set provides a satisfactory basis for enunciating an absolute rule governing vacatur.

\section{A. Private Interests}

Parties to a dispute seek favorable resolution while conserving resources and preserving autonomy. When litigation ensues, parties do not renounce these private interests. If adjudication is viewed as a means to individual dispute resolution, then outcomes negotiated by the parties merit respect. Our jurisprudence recognizes these private interests of conservation and autonomy in terms of a strong preference for settlement. ${ }^{41}$ By terminating

37. According to former Chief Justice Burger, "we should provide mechanisms that can produce an acceptable result in the shortest possible time, with the least possible expense, and with a minimum of stress on the participants. That is what justice is all about." Burger, Isn't There a Better Way?, 68 A.B.A. J. 274, 274 (1982). He asserts that courts should not be expected to fulfill the functions that are properly the concern of church, family, and neighborhood. Id. at 275. The former Chief Justice's views are often associated with the Alternative Dispute Resolution (ADR) movement. See, e.g., Fiss, Against Settlement 93 YALE L.J. 1073, 1073 (1984).

Martin Shapiro, an ADR theorist, elaborates a "universal" dispute-resolution model. M. SHAPIRo, Courts 1-2 (1981). For Shapiro, conflict is structured in triads. When two persons in a state of nature cannot resolve a dispute, common sense dictates that they will call upon a stranger to assist. However, "[i]n the hypothetical state of nature where the dispute resolution story transpires, there are no public values or goals, only the private desires of individuals." Fiss, The Social and Political Foundations of Adjudication, 6 LAw \& HuM. BEHAv. 121, 123 (1982).

38. Owen Fiss is the most consistent proponent of this societal-justice view of adjudication. Courts, according to Fiss, are public resources run by public officials whose power is defined and conferred not by private agreement, but by public law. Fiss, Against Settlement, supra note 37, at 1085. Fiss envisions the task of adjudication as "not to maximize the ends of private parties, nor simply to secure peace, but to explicate and give force to the values embodied in authoritative texts such as the Constitution and statutes: to interpret those values and to bring reality into accord with them." Id.

39. Suits by private attorneys general illustrate the simultaneous pursuit of private and public goals. See, e.g., Newman v. Piggie Park Enters., 390 U.S. 400, 401-02 (1968) (per curiam) (when plaintiff obtains injunction under Civil Rights Act of 1964, plaintiff vindicates public interest of "highest priority"); see also Fortner Enters. v. United States Steel Corp., 394 U.S. 495, 502 (1969) ("As the special provision awarding treble damages to successful plaintiffs illustrates, Congress has encouraged private antitrust litigation not merely to compensate those who have been directly injured but also to vindicate the important public interest in free competition." (citation omitted)).

40. In Nestle, the court of appeals saw no justification for forcing Saccone to act as a private attorney general. 756 F.2d at 284 .

41. "Settlement agreements are highly favored in the law and will be upheld whenever possible . . . ." Pearson v. Ecological Science Corp., 522 F.2d 171, 176 (5th Cir. 1975) (quoting D. H. Overmyer Co. v. Loflin, 440 F.2d 1213, 1215 (5th Cir.), cert. denied, 404 U.S. 851 (1971), cert. denied, 425 U.S. 912 (1976); see also WRIGHT, MILLER \& COOPER, supra note 23, $\$ 3533.10$ (voluntary settlement so important that parties should be free to agree to destroy preclusive effect of 
litigation, settlement resolves uncertainties, restores amicable relations, limits court costs, and frees the parties to concentrate on more productive activities. ${ }^{42}$ Negotiated outcomes enhance efficiency and decrease the risk of unacceptable, imposed solutions.

In Nestle, vacating the trademark invalidity judgment cleared the way for settlement of all remaining claims. In contrast to the outcome generated by the district court, ${ }^{43}$ the parties achieved a comprehensive solution including agreements covering trademark, service mark, and trade name. ${ }^{44}$ Settlement effectively terminated litigation between the parties. Nestle and Saccone thus avoided the expense and risk of appellate proceedings, Nestle surrendered its right to appeal, and both parties incurred limited negotiation costs. Denying this expression of party autonomy would have been especially burdensome to Saccone, which would then have been compelled to respond to an appeal ${ }^{45}$-or negotiate a less favorable settlement-only because of Nestle's assessment of the merits of future cases.

\section{B. Public Interests}

Settlement conditioned upon vacatur of a final judgment, however, cannot be viewed solely in context of the immediate parties. ${ }^{48}$ Circumventing preclusion by vacating existing judgments threatens the public interests in finality of judgments, judicial economy, legitimacy of the legal system, and consistency.

Issue preclusion promotes finality of judgments by preventing endless relitigation of issues. ${ }^{47}$ Public expectations require such finality. ${ }^{48}$ Precluding relitigation of common issues spares the resources of $\operatorname{courts}^{48}$ and

entered judgment).

42. For a brief but comprehensive summary of the costs of litigation, see JAMES \& HAZARD, supra note $1, \S 6.3$.

43. Nestle, 571 F. Supp. at 766-68 (bare conclusion that "Toll House" generic).

44. See Nestle, 596 F. Supp. at 1446.

45. See Nestle, 756 F.2d at 284 . This problem manifests the general tendency of issue preclusion to distort the first case in which a common issue is contested. Flanagan, Offensive Collateral Estoppel: Inefficiency and Foolish Consistency, 1982 ARIz. ST. L.J. 45, 54. Contra Schroeder, supra note 6 , at 956-57.

46. Fairness goes beyond the parties in an individual case "to all who use or wish to use the litigation system." Newman, Rethinking Fairness: Perspectives on the Litigation Process, 94 Yale L.J. 1643, 1644 (1985).

47. See, e.g., Angel v. Bullington, 330 U.S. 183, 192-93 (1947); Reardon v. Allen, 88 N.J. Super. 560, 565-66, 213 A.2d 26, 28-29 (Law Div. 1965); see also Pielemeier, Due Process Limitations on the Application of Collateral Estoppel Against Nonparties to Prior Litigation, 63 B.U.L. REv. 383, 394 n.68 (1983) (listing articles stating that preclusion rules promote finality); $f$. Resnik, Precluding Appeals, 70 Cornel. L. REv. 603, 611 (1985) (finality is valued feature of litigation process).

48. See Pielemeier, supra note 47, at 394 n.69 (listing articles stating that issue preclusion promotes consistency and finality, and therefore breeds public confidence in courts); Resnik, supra note 47, at 619 (finality is "desirable psychological state"). Pielemeier, supra note 47, conveniently presents authorities for each public interest identified herein.

49. See Pielemeier, supra note 47, at 394 (issue preclusion said to decrease number of suits, thus 
witnesses. ${ }^{\mathbf{B 0}}$ Further, rules of preclusion direct the flow of judicial resources away from repetitive litigation and toward new issues of fact and law, thus serving allocative efficiency. ${ }^{51}$ Finality through issue preclusion also imposes consistency, which in turn promotes the legitimacy of the legal system. ${ }^{\text {B2 }}$

Settlement conditioned on vacatur, on the other hand, decreases public respect for the legal establishment by encouraging wealthy litigants to sue until reaching favorable outcomes, to conspire against the interests of unrepresented future litigants, and to utilize public resources and then discard the results. ${ }^{53}$ Essentially, settlement conditioned on vacatur eliminates certain returns on the public investment in a trial ${ }^{\text {s4 }}$ by circumventing operation of issue preclusion and thus jeopardizing finality of judgments, economy, legitimacy, and consistency. In so doing, settlement conditioned on vacatur allows the present parties to appropriate from unrepresented third parties ${ }^{55}$ a portion of the value of public adjudication. ${ }^{\text {ss }}$

clearing dockets, reducing delay in trials, and increasing quality of decisions) \& nn.61, 63 \& 66 (citing articles). Contra Flanagan, supra note 45 , at 60 (tentative empirical data do not support such reduction in litigation). But see Callen, Efficiency After All: A Reply to Professor Flanagan's Theory of Offensive Collateral Estoppel, 1983 ARIz. Sr. L.J. 799, 826-30 (Flanagan is incorrect: Issue preclusion limits wasteful expenditure of judicial and litigant resources). While settlement conditioned on vacatur avoids appeal, it allows future relitigation which is far more time-consuming and costly. See Chemetron Corp. v. Business Funds, Inc., 682 F.2d 1149, 1190 n.85 (5th Cir. 1982), cert. denied, 460 U.S. 1013 (1983). But see Nestle, 756 F.2d at 282.

50. See Note, Preclusion of Absent Disputants To Compel Intervention, 79 ColuM. L. REv. 1551, 1551 (1979) [hereinafter Note, Absent Disputants].

51. See Blonder-Tongue Laboratories, Inc. v. University of Ill. Found., 402 U.S. 313, 329 (1971) (relitigation of issue previously determined is misallocation of resources); Nestle, $596 \mathrm{~F}$. Supp. at 1452; Pielemeier, supra note 47, at 394 n.62 (listing articles stating that preclusion renders expenditure of judicial resources more efficient).

52. See Pielemeier, supra note 47 , at $394 \mathrm{nn.67} \& 69$ (listing articles stating that issue preclusion imposes consistency on and enhances public confidence in courts). However, consistency may be achieved only by sacrificing truth in individual cases. Comment, Nonparties and Preclusion by Judgment: The Privity Rule Reconsidered, 56 CALIF. L. REv. 1098, 1100 (1968) [hereinafter Comment, Privity Rule]; see also Schroeder, supra note 6, at 944 (impossible to be confident that first decision on issue should control future litigation); Resnik, supra note 47, at 615-16, 621 (correctness of determination of issue is "highly problematic concept").

53. Plaintiffs who switch adversaries so as to retry issues previously lost are "trifling with the public interest." Currie, supra note 4 , at 301.

54. The government subsidizes litigation by providing, for example, judges' salaries and courthouses. R. POSNer, Economic Analysis of Law 493 (3d ed. 1986). This government investment produces three types of societal benefits. First, adjudication resolves disputes, and thus preserves public order by eliminating the need for self-help. Second, courts produce opinions, the value of which inures to people having little connection to the case at hand. Id. at 493-94. Third, in cases giving rise to future issue preclusion, conclusive determination of issues frees courts and future parties from costs of relitigation.

Settlement conditioned on vacatur deprives the public of this third type of benefit. Furthermore, such settlements may weaken the precedential value of opinions. See supra note 23.

55. These parties are future litigants with an interest in avoiding relitigation of issues determined in the first case.

56. This redistribution takes the form of altered settlement values. See Note, An Analysis of Settlement, 22 STAN. L. REv. 67 (1969) (providing framework for evaluating settlement values). Redis- 
Assume, for example, that Nestle originally chose not to join Chips as a codefendant. After vacating the Saccone judgment and thus freeing itself from future preclusion, Nestle initiates a similar action against Chips and wins despite relitigation of identical issues. Clearly, with respect to these issues, finality and consistency are thwarted. The two fully litigated cases have created costs for two sets of courts, defendants, and witnesses. Nestle's success at buying a new hearing ${ }^{67}$ offends judicial integrity.

Public interests are not, however, uniformly arrayed against settlement conditioned on vacatur. First, the party fearing preclusive effects may appeal solely to reverse one of several alternative and independent grounds for the judgment. ${ }^{88}$ If successful, such an appeal would serve only to eliminate issue preclusion while leaving the judgment standing on other grounds. Compared with settlement, such appeals waste judicial resources and are unfair to appellees. Second, the trial court's determination may simply be wrong; certainly, mistakes occur. ${ }^{69}$ A party's election to settle

tribution may be illustrated by a three-party model. Assume P1 and P2 have identical potential claims, with identical settlement values $\left(S_{0}\right)$, against a common defendant $D$. P1 files suit and wins a cash judgment. The settlement value of P1's claim rises to $S_{1}$, reflecting $P 1$ 's victory at trial but anticipating further costs and the possibility of loss on appeal. The settlement value of P2's claim also rises, to $S_{2}$, because the possibility of issue preclusion both reduces P2's expected trial costs and increases P2's chances for victory in a second action.

Now assume P1 and D settle conditioned on vacatur at a value equal to $S_{3}$ (greater than $S_{1}$ ). Because $D$ would then be free of preclusive effect, the settlement value of P2's claim reverts to $S_{0}$. The difference between $S_{2}$ and $S_{0}$ is shared by $P 1$ and $D$; the allocation between them depends on the actual value of $S_{3}$.

-Note that if multiple suits may drive $\mathrm{D}$ into bankruptcy, these calculations become much more complex.

57. If vacatur were granted routinely to effectuate settlements conditioned on vacatur, "any litigant dissatisfied with a trial court's findings would be able to have them wiped from the books." Ringsby Truck Lines v. Western Conference of Teamsters, 686 F.2d 720, 721 (9th Cir. 1982). By allowing a party fearing preclusion to destroy future preclusive effect merely by giving up its right to appeal and paying off the appellee, such a rule would undermine the risks of going to trial throughout the judicial system. Note, Postjudgment Settlements, supra note 25 , at 353,368 .

58. The preclusive effect of judgments supported by alternative and independent grounds is unclear. The Restatement provides: "If a judgment of a court of the first instance is based on determinations of two issues, either of which standing independently would be sufficient to support the result, the judgment is not conclusive with respect to either issue standing alone." RestATEMENT, supra note $2, \$ 27$ comment $\mathrm{i}$. The Restatement relies heavily on Halpern v. Schwartz, 426 F.2d 102 (2d Cir. 1970).

The Restatement rule has been vigorously criticized. See Lucas, The Direct and Collateral Estoppel Effects of Alternative Holdings, 50 U. GHI. L. REv. 701 (1983). The rule allowing relitigation of issues forming independent bases for a judgment, Lucas argues, is inefficient and unfair. Id. at 729-30. Such a rule "would merely preserve an odd little corner of the mutuality doctrine without special justification." Id. at 730. Lucas also questions the Restatement's reliance on Halpern. Decided before the marked shift in issue preclusion doctrine precipitated by Blonder-Tongue Laboratories, Inc. v. University of Ill. Found., 402 U.S. 313 (1971), Halpern has been confined to its facts and treated cautiously in other jurisdictions. Lucas, supra, at 729.

Despite the Restatement position, alternative and independent grounds can serve as a predicate for issue preclusion in some jurisdictions. See Malloy v. Trombley, 50 N.Y.2d 46, 49-54, 405 N.E.2d 213, 213-16, 427 N.Y.S.2d 969, 970-73 (1980); Patterson v. Saunders, 194 Va. 607, 611, 74 S.E.2d 204, 207 (1953).

59. See supra note 52 . 
conditioned on vacatur may indicate that it expects to win the issue upon relitigation.

\section{G. Failure of Absolute Standards}

Essentially, settlement conditioned upon the vacatur of entered judgments sets up a mutually exclusive relationship between private and public interests. Whether one favors public or private concerns is determined by one's view of the role of adjudication within society ${ }^{80}$ The avoidance of preclusive effects by settlement conditioned on vacatur transcends the models at the heart of both public and private conceptions of adjudication. ${ }^{61}$ These conceptions therefore cannot provide a basis for uniformly

60. For a discussion of the ADR view, see supra note 37. For a discussion of the opposing Fissian societal-justice view, see supra note 38 .

Owen Fiss makes this public-private distinction explicit. Fiss, Against Settlement, supra note 37, at 1089 (some see adjudication in private terms, its purpose being to resolve disputes; "[Fiss], on the other hand, see[s] adjudication in more public terms: Civil litigation is an institutional arrangement for using state power to bring a recalcitrant reality closer to our chosen ideals"). The disputeresolution view begins with the proposition that, "[a]t bottom, ours is a society built on individualism, competition, and success." Bok, A Flawed System, HARv. MAG., May-June 1983, at 42. When pursuit of these values causes individual conflicts, adjudication should provide a process of reconciliation. McThenia \& Shaffer, For Reconciliation, 94 YALE L.J. 1660, 1664 (1985) (replying to Fiss, Against Settlement, supra note 37). Justice is not something people get from government; rather, justice is something people give each other. McThenia \& Shaffer, supra, at 1664-65.

The ADR notion of adjudication strongly favors settlements because they express reconciliation between parties. Applied to settlement conditioned on vacatur, this view unfolds as follows:

All of the policies that make voluntary settlement so important a means of concluding litigation apply. The appellee as well as the appellant may prefer settlement, and can bargain for whatever future protection it needs. It cannot be argued that the possible nonmutual preclusion interests of nonparties justify either appellate decision against the wishes of the parties, or an insistence that as a price of settlement the appellant must permit the district court judgment to support nonmutual preclusion. The parties should remain free to settle on terms that require vacation of the judgment, entry of a new consent judgment, or such other action as fits their needs.

Wright, MILler \& CoOPER, supra note $23, \S 3533.10$ (footnote omitted).

Fiss agrees that parties should not be forced to commence litigation. Fiss, Against Settlement, supra note 37, at 1085. However, once parties turn to the courts, he thinks it absurd to encourage settlement, Fiss, Out of Eden, 94 YALE L.J. 1669, 1670 (1985), because to do so would deprive society of the benefits of litigation, Fiss, Against Settlement, stupra note 37 , at 1085 . In comparison with judgment entered by a court and supported by a written opinion, Fiss finds settlement "highly problematic." Id. at 1075 . He claims that there is and should be a "conceptual and normative distance" between what parties do and what courts decide. See id. at 1080.

What divides Fiss and the ADR movement "is not that [they] are concerned with different universes of cases." Id. at 1089. The schism "is much deeper and stems from [their] understanding of the purpose of the civil law suit and its place in society." Id.

61. Recall Shapiro's triadic model, supra note 37 , which lies at the heart of dispute resolution views of adjudication. In a state of nature, two persons reach an impasse and bring in a neutral stranger to decide. The triad possesses a basic social logic, which vanishes when the stranger makes a decision, because the triad then becomes two-against-one. Shapiro claims that much court behavior is aimed at mitigating the two-against-one nature of adjudication. M. SHAPIRO, supra note 37, at 2.

This model is very limited; it assumes away public interests. Further, the triad concept fails adequately to encompass settlement conditioned upon vacatur. Where the disputants confront the stranger with a joint proposal, future litigants of like issues constitute the "outnumbered" party, and future litigants are external to the triadic model.

Fiss's structural-reform view of adjudication also relies on an inadequate model of adjudication. 
preferring either public or private interests. A rule calling for mandatory denial -or mandatory vacatur-fails to ensure uniformly just results; ${ }^{\mathbf{6 2}}$ such an absolute rule would merely determine the parameters of the settlement game. ${ }^{6 s}$

\section{Grafting Relative Standards}

Rules of preclusion embody a compromise between private and public interests. Settlement conditioned on vacatur draws private and public interests into confrontation precisely because such settlement avoids issue preclusion. This Note therefore fashions standards of decision that restore the balance between private and public interests implicit in the doctrine of issue preclusion. ${ }^{84}$ By exploring the traditional adversarial model of adjudication, this Note proceeds to examine how rules of issue preclusion mediate between private and public interests.

\section{A. Issue Preclusion and the Traditional Model of Adjudication}

Five elements characterize our "received tradition" of adjudication. ${ }^{65}$ First, the lawsuit is bipolar, engaging two diametrically opposed parties. Second, litigation is retrospective; the dispute concerns discrete, complete, past events. Third, right and remedy are interdependent. Fourth, actions are self-contained: Judgment affects only the two parties and terminates judicial involvement. Finally, litigation is party-initiated and partycontrolled. ${ }^{\text {B8 }}$

McThenia \& Shaffer, supra note 60, at 1662-63. Communication is disrupted, asserts Fiss, when a community is fractionated, distributional inequalities dominate, or communal norms are misunderstood. "Adjudication is but a response to this predicament. It is a social process that uses the power of the state to require the reluctant to talk and to listen ... ." Fiss, Out of Eden, supra note 60, at 1672. This model of dispute resolution manifestly fails to encompass the problem posed by two parties jointly moving to vacate a judgment in order to destroy preclusive effect.

62. "The answer may be different in different cases as equities and hardships vary the balance between the competing values of right to relitigate and finality of judgment." Ringsby Truck Lines v. Western Conference of Teamsters, 686 F.2d 720, 722 (9th Cir. 1982) (citation omitted).

63. Settlement conditioned on vacatur redistributes part of the value of the initial case from third parties to the initial parties. See supra note 56. However, this redistribution from $P 2$ to $P 1$ and $D$ does not provide a basis for choosing an absolute rule governing vacatur. Issue preclusion forces $\mathrm{P1}$ and $\mathrm{D}$ to provide benefits for P2; it distorts the initial case. See supra note 45 . The common party D must "over-litigate" the case; consequently, P1 also suffers. Settlement conditioned on vacatur allows $\mathrm{P} 1$ and D to recover some of the costs of the first-case distortion. P2 is left in a position no worse than if it had tried the case first.

64. Molded within the public-private dialectic, these standards of decision reflect the fact that issue preclusion is inherently a compromise, see Lyons v. Westinghouse Elec. Corp., 222 F.2d 184, 189 (2d Cir. 1955) (doctrine of res judicata "must be treated as a compromise between two conflicting interests: the convenience of avoiding a multiplicity of suits and the adequacy of the remedies afforded for conceded wrongs"); Comment, Privity Rule, supra note 52, at 1100 (conflict may only be resolved, albeit unsatisfactorily, by "recognizing that truth is a relative concept, and that justice can only prevail with a balancing of competing interests").

65. See Chayes, supra note 23 , at 1282-83 (traditional conception of adjudication).

66. Id. at 1282-83, 1285-88. Chayes admits that his encapsulation of the traditional model is 
Factual patterns giving rise to issue preclusion defy rigid application of this traditional model because they are neither bipolar nor self-contained. When a party faces a sequence of opponents litigating similar issues, a fundamental tension arises between justice in individual cases and overarching problems of judicial economy, finality of judgments, and consistency.

Consider the following products liability example: Manufacturer D sells a product which is widely marketed. The product injures-and will continue to injure-numerous individuals $\mathrm{P} 1, \mathrm{P} 2, \mathrm{P} 3$, etc. $\mathrm{P} 1$ is the first to bring suit. The litigation follows the traditional model: It is partyinitiated and formally bipolar. However, in substance, the dispute between $\mathrm{P} 1$ and $\mathrm{D}$ affects the interests of all other injured parties. The first action is not self-contained, for a stream of like claims will soon confront D.

Party autonomy is a major motivating factor in the received adversary system. ${ }^{67} \mathrm{P} 1, \mathrm{P} 2, \mathrm{P} 3$, etc. are free to initiate separate suits at different times in different forums. ${ }^{68}$ However, P1, P2, . ., P37 would ideally all be in court together, to adjudicate D's liability. ${ }^{69}$ In the absence of universal joinder, the doctrine of issue preclusion imposes a degree of judicial economy, finality, legitimacy, and consistency upon the party-oriented operation of the traditional adversary system. The possibility of vacating entered judgments to erase future preclusive effects distorts the established balance of issue preclusion.

\section{B. The Offensive/Defensive Distinction}

In defining the proper compromise between individual and societal justice, courts and commentators have distinguished cases according to which

overdrawn; nevertheless, he asserts that it is so firmly rooted in our understanding and analysis of the legal system as to be taken for granted. Id. at 1283. Chayes' model of the traditional conception of adjudication has been applied to the analysis of issue preclusion. See Flanagan, supra note 45 , at 50 n.33.

67. Chayes, supra note 23 , at 1285 .

68. Liberalization of joinder and pleadings-and the drastic expansion of the number of potential plaintiffs-has put great pressure on the traditional adversary system. Id. at 1289-91. Rules of venue, service of process, and personal jurisdiction contribute to the dispersion of multiparty suits across many forums. Note, Absent Disputants, supra note 50, at 1555. For an illustration, see Currie's train crash example, supra note 4.

69. Joinder of multiple plaintiffs is available only in very limited situations. Schroeder, supra note 6, at 917; Note, Absent Disputants, supra note 50, at 1554 \& n.20; see infra note 87 and accompanying text. Even if there were a mandatory procedure for bringing all parties into the same court at the same time, the ideal could not always be achieved. In the context of a mass tort with a long latency period, P10 and P37 might not yet have become aware of any injury. "[T]he nonsimultaneous harm case presents problems different from those of the traditional bi-polar model of litigation." Flanagan, supra note 45 , at 68 (footnote omitted) (citing Chayes, supra note 23, at 1282-83). 
party is precluded from relitigating common issues. ${ }^{70}$ Commentators have often discussed this distinction in terms of offensive and defensive use of issue preclusion. ${ }^{71}$ Offensive issue preclusion "occurs when the plaintiff seeks to foreclose the defendant from litigating an issue the defendant has previously litigated unsuccessfully in an action with another party." the products liability example above ${ }^{23}$ if injured party $\mathrm{P} 1$ wins a judgment against manufacturer D, P2's invocation of issue preclusion against D would constitute offensive use. Conversely, defensive use of issue preclusion occurs when a defendant seeks to prevent a plaintiff from asserting a claim the plaintiff has previously litigated and lost against a different defendant. ${ }^{74}$ In the extended Nestle example, Chips would employ defensive issue preclusion to prevent plaintiff Nestle from relitigating issues it has already lost against Saccone.

In 1971, the Supreme Court greatly expanded the scope of defensive issue preclusion, allowing defendants not party to a prior action to invoke the prior judgment against the common plaintiff. ${ }^{75}$ Nine years later, in Parklane Hosiery Co. v. Shore, ${ }^{76}$ the Court placed offensive preclusion on much the same footing; currently, prior judgments may be invoked against common defendants as well. ${ }^{77}$ The Court noted that, unlike defensive preclusion, offensive preclusion creates disincentives to joinder:

[O]ffensive use of collateral estoppel does not promote judicial economy in the same manner as defensive use does. Defensive use of collateral estoppel precludes a plaintiff from relitigating identical issues by merely "switching adversaries." Thus defensive collateral estoppel gives a plaintiff a strong incentive to join all potential defendants in the first action if possible. Offensive use of collateral estoppel, on the other hand, creates precisely the opposite incentive. Since a plaintiff will be able to rely on a previous judgment against a defendant but will not be bound by that judgment if the defendant wins, the plaintiff has every incentive to adopt a "wait and see" attitude, in the

70. See, e.g., Parklane Hosiery Co. v. Shore, 439 U.S. 322, 329-31 (discussing offensive/defensive distinction in case law), 329 n.11 (citing articles expressing reservations regarding application of offensive issue preclusion) (1979).

71. The classic piece on this aspect of issue preclusion remains Currie, supra note 4 (introducing terms "offensive" and "defensive").

72. Parklane Hosiery, 439 U.S. at 326 n.4.

73. See supra text accompanying notes 67-69.

74. Parklane Hosiery, 439 U.S. at 326 n.4.

75. See Blonder-Tongue Laboratories, Inc. v. University of Ill. Found., 402 U.S. 313 (1971).

76. 439 U.S. 322 (1979).

77. Id. at 331. Shore brought a stockholders' class action against Parklane Hosiery for issuing a materially false and misleading proxy statement. In an earlier case, the Securities and Exchange Commission (SEC) had made the same allegation and won; therefore, Shore moved for partial summary judgment, invoking the SEC action to preclude relitigation by Parklane Hosiery of issues resolved therein. The Court granted partial summary judgment. 
hope that the first action by another plaintiff will result in a favorable judgment. ${ }^{28}$

The Court also noted that offensive use of issue preclusion is potentially unfair to the common defendant. ${ }^{79}$

Nevertheless, the Supreme Court enunciated a general rule granting trial courts discretion to determine when to apply preclusion. ${ }^{80}$ By extending third-party preclusion to cover invocation against common defendants as well as common plaintiffs, ${ }^{81}$ Parklane Hosiery de-emphasized the offensive/defensive distinction.

The Parklane Hosiery decision adequately addresses problems of joinder and unfairness at the time when issue preclusion is invoked. When viewed at the time the initial plaintiff and defendant jointly move to vacate, however, problems of joinder and unfairness emerge anew.

\section{The Proposed Solution}

Settlement conditioned on vacatur, with its problems of joinder and unfairness, must be brought within the public-private balance of issue preclusion. Thus, the solution to the problems posed by settlement conditioned on vacatur must be pursued along the lines of the defensive/ offensive distinction. The proposed rule calls for denial of vacatur when a plaintiff seeks to escape preclusive effect, but for discretionary granting of vacatur when a defendant desires freedom to relitigate.

78. Id. at 329-30 (citations and footnote omitted); see Reardon v. Allen, 88 N.J. Super. 560, 571-72, 213 A.2d 26, 32 (Law Div. 1965); Berch, A Proposal To Permit Collateral Estoppel of Nonparties Seeking Affirmative Relief, 1979 ARIz. ST. L.J. 511, 530-31; Semmel, Collateral Estoppel, Mutuality and Joinder of Parties, 68 Colum. L. REv. 1457, 1473 (1968); Note, Absent Disputants, supra note 50, at 1554; Comment, Mandatory Intervention: Expansion of Collateral Estoppel in Favor of Single Defendants Against Multiple Plaintiffs in Federal Civil Litigation, 14 J. MARSHAL.L L. Rev. 441, 442 (1981); see also JAMES \& HAzARD, supra note 1, § 11.24 ("great disparity in litigating risks"). Where defensive use promotes judicial economy by forcing plaintiffs to join all defendants, offensive use promotes unfairness and waste. Comment, supra, at 451 .

79. If the first plaintiff sues for damages inadequate to elicit a vigorous defense, if the judgment relied upon is inconsistent with previous judgments, or if "the second action affords the defendant procedural opportunities unavailable in the first action," then offensive use may be unfair. Parklane Hosiery, 439 U.S. at 330-31; see also Restatement, supra note 2, $\$$ 28(5)(c), 29(2), 29(4). Thus, precluding relitigation of an issue may be unfair. In other circumstances, permitting relitigation may be unfair. See infra notes 82-84 and accompanying text (problem of harassment). In this Note, "unfairness" encompasses both of these ideas. Cf. Newman, supra note 46 (advocating broadened concept of procedural fairness).

80. Parklane Hosiery, 439 U.S. at 331 . Where a party not in the original suit invokes issue preclusion, additional considerations may indicate the inappropriateness of preventing relitigation of an issue. These parameters are set out in the Restatement, supra note $2, \S 29$. See discussion infra notes 89-96 and accompanying text.

81. See Parklane Hosiery, 439 U.S. at 331-33. 


\section{Plaintiff Seeks To Avoid Issue Preclusion}

In cases giving rise to prospective defensive use of issue preclusion, settlement conditioned on vacatur should be prohibited; to allow it would threaten the judicial values of legitimacy, economy, finality of judgments, and consistency, while introducing problems of joinder and harassment. Where parties jointly move to vacate so as to free a plaintiff from the possibility of future preclusion, the most pressing problem is unfairness to unrepresented potential defendants, ${ }^{82}$ and this unfairness may never surface in court. Defensive issue preclusion gives common plaintiffs strong incentives to join all potential defendants in one action, ${ }^{83}$ but if vacatur is allowed, a losing plaintiff can instead buy off preclusive effect, then attack single defendants and coerce favorable settlements by threatening litigation. ${ }^{84}$

On these grounds, the court of appeals should have affirmed the district court's decision in Nestle. Because Nestle was allowed to circumvent a judgment holding "Toll House" to be generic, Nestle can now pursue toll house cookie bakers individually, by threatening suits and forcing settlements or by relitigating trademark infringement issues. Where a plaintiff seeks to avoid future preclusion, the judgment should stand because public interests dominate. ${ }^{85}$

82. It cannot be claimed, however, that forcing future defendants to litigate issues previously lost by plaintiff is unfair to the defendants. Had the second or third defendant been sued first instead, it would have had to bear the costs of litigating these issues. See Flanagan, supra note 45, at 52; Note, Nonmutuality: Taking the Fairness out of Collateral Estoppel, 13 IND. L. REV. 563, 571 (1980). Rather, the unfairness lies in plaintiff's out-of-court harassment of potential defendants. See infra note 84 and accompanying text.

83. See supra text accompanying note 78 (quoting Parhlane Hosiery, 439 U.S. at 329-30).

84. Such coercive behavior may stem from disparity of available resources. See Fiss, Against Settlement, supra note 37, at 1076. First, a poorer defendant may be disadvantaged in the bargaining process because it is less able to process the information and predict the outcome of litigation. Second, the threatened defendant may be unable to finance its own litigation expenses (such as legal fees) or expenses imposed by its opponent (such as discovery costs). Id.

Unequal bargaining power arises in other situations as well; for example, a statutory presumption may make a suit very costly to defend. The Blonder-Tongue case combined the elements of disparate resources and costly defense. See Blonder-Tongue Laboratories, Inc. v. University of Ill. Found., 402 U.S. 313, 334-48 (1971). The presumption of patent validity plus the nature of infringement litigation made the defense extremely costly. In such actions, "the very survival of the small businessman may be at stake." Id. at 342 (quoting from Senate subcommittee hearing on patent law revision). "As a consequence, prospective defendants will often decide that paying royalties under a . . . settlement is preferable to the costly burden of challenging the patent." Id. at 338. "[T]he threat alone [may be] sufficient to forestall a challenge to the patent." Id. at 339. A "patentee, having been afforded the opportunity to exhaust his remedy of appeal from a holding of invalidity, has had his "day in court' and should not be allowed to harass others on the basis of an invalid claim." Id. at 339-40 (quoting President's Commission on the Patent System); of. Blue Chip Stamps v. Manor Drug Stores, 421 U.S. 723, 741 (1975) (discussing "strike" suits in securities fraud cases-suits in which a complaint with very little chance of success on the merits may have "in terrorem" increment of settlement value).

85. This is not to say that countervailing interests do not exist; issue preclusion is a compromise doctrine. See supra note 64 . Perhaps solely because of the plaintiff's assessment of preclusion in future 


\section{Defendant Seeks To Avoid Issue Preclusion}

Settlement conditioned on vacatur should be discretionary in cases potentially giving rise to offensive issue preclusion. The availability of offensive preclusion actually discourages the litigation of all similar issues in a single case. First, potential plaintiffs have every reason not to intervene in the first action. ${ }^{86}$ Second, common defendants rarely join additional plaintiffs. $^{87}$ Settlement conditioned on vacatur to protect a defendant from preclusion therefore does not present problems of joinder. In addition, vacatur in the offensive context does not promote unfairness and harassment. ${ }^{88}$ Because plaintiffs initiate lawsuits, defendants fearing preclusion are not positioned to shop for favorable judgments by settling conditioned on vacatur.

Where a defendant seeks freedom to relitigate issues, problems of joinder or harassment do not arise, so vacatur should be granted or denied according to individual fact patterns. The trial court should carefully weigh private and public interests in exercising discretion.

\section{a. Conditions Governing Discretion}

In order to re-establish the equilibrium between private and public interests created by rules of issue preclusion, the trial court should apply the conditions which, if the judgment had been allowed to stand, would govern invocation of preclusion against the defendant in the second forum. ${ }^{89}$ Only some of these factors will be within the trial court's competence at the time of the motion to vacate. ${ }^{90}$ Thus, the following conditions should

cases, the defendant in the first action must undertake the expense and risk of appeal. See supra text accompanying note 45 . Thus, denial of a joint motion to vacate does not give unlimited latitude to party autonomy. Note, however, that before any parties attempted settlement conditioned on vacatur, the doctrine of issue preclusion tolerated such unfairness. Also, the proposed rule does not seem unfair to the common plaintiff: "[W]e should keep firmly in mind that we are considering the situation where the . . . plaintiff in the prior suit . . . chose to litigate at that time and place. Presumably he was prepared to litigate and to litigate to the finish against the defendant there involved." BlonderTongue, 402 U.S. at 332.

86. See supra note 78 and accompanying text.

87. JAMES \& HAZARD, supra note $1, \S 11.24$. Defendants faced with multiple claimants may dispose of the question of liability by bringing an action for declaratory judgment against all claimants. Id. (citing Pennsylvania R.R. v. United States, 111 F. Supp. 80 (D.N.J. 1953)). Such actions are rare; common defendants apparently do not wish to risk stimulating "claims that might otherwise remain dormant." JAMES \& HAZARD, supra note $1, \S 11.24$.

88. The common defendant does not "control the time, the place or the conditions of the first trial." Currie, supra note 4, at 301 (footnote omitted). Therefore, the common defendant cannot unjustly switch adversaries, see id. at 300 , when settlement conditioned on vacatur removes the possibility of issue preclusion.

89. See RESTATEMENT, supra note $2, \$$ 27-29.

90. The Restatement, id. $\S 29(2)$, requires that the second forum take into account whether it affords the party sought to be precluded procedural opportunities that were not available in the first action. However, when the parties to the initial action move to vacate, the trial court probably will not know the circumstances of other suits against the same defendant. Section 29(3) directs the second 
be considered in vacating the judgment: inconsistency with prior judgments, ${ }^{91}$ ambivalence of the determination, ${ }^{92}$ existence of alternative independent bases for the holding, ${ }^{93}$ lack of adequate opportunity or incentive for defendant to obtain full and fair adjudication, ${ }^{94}$ and incompatibility of future preclusion with an applicable remedial scheme..$^{95}$ Additional factors leading the trial court to vacate should include low cost of relitigating the issue, resolution of other pending or potential suits as part of the proposed settlement, and assessment of the defendant's good faith in choosing trial over settlement prior to judgment. Thus, trial judges should vacate to effectuate settlement when a case is close ${ }^{96}$ or when a judgment is unlikely to be invoked successfully to preclude relitigation of issues. ${ }^{97}$

forum to consider whether "[t]he person seeking to invoke favorable preclusion, or to avoid unfavorable preclusion, could have effected joinder in the first action between himself and his present adversary." In the original suit, when the parties propose settlement conditioned on vacatur, the court may not be aware of joinder possibilities. Similar arguments apply to $\S 29(6)$ (" $[$ t]reating the issue as conclusively determined may complicate determination of issues in the subsequent action or prejudice the interests of another party thereto"), and $\S 29(7)$ ("[t]he issue is one of law and treating it as conclusively determined would inappropriately foreclose opportunity for obtaining reconsideration of the legal rule upon which it was based").

Thus, vacatur triggers an allocation of the tasks required to evaluate issue preclusion against the common defendant in a second suit. If the first court vacates, preclusion may not be invoked on the basis of that court's judgment. If the first court refuses to grant vacatur, it should specify the factors influencing its decision. When another defendant seeks to preclude defendant from relitigating in a second forum issues already determined, the second court should weigh the remaining conditions governing application of preclusion.

This allocation of duties may tend towards judicial economy. Secondary forums will have fewer factors to assess. Also, the common defendant and secondary plaintiffs will have a clearer understanding of the likelihood of preclusion. They presumably will make more efficient choices between settlement and litigation.

91. Id. $\S 29(4)$ (initial determination itself inconsistent with another determination of same issue). Despite the fact that a joint motion to vacate temporarily suspends the adversarial nature of the proceeding, inconsistency with prior judgments may easily be determined by the trial court.

92. Id. $\S 29(5)$ (initial determination affected by relationships unique to parties, or based on compromise verdict or finding); see id. $\$ 29$ comment $\mathrm{g}$ ("Particularly where the issues have been tried to a jury, the circumstances may suggest that the issue was resolved by compromise or with more or less conscious reference to such matters as insurance coverage or the litigants' relative financial position."); see also Flanagan, supra note 45, at 72 (judges have opinions on soundness of factual issues decided by juries).

93. RESTATEMENT, supra note $2, \S 27$ comment $i$; see supra note 58 and accompanying text. In non-jury trials, the court alone can answer this question.

94. RESTATEMENT, supra note 2, § 28(5)(c).

95. Id. $\S 29(1)$. For example, "if a statute provides that a determination is limited to the action in which it is made, or that it is to be treated in subsequent actions as only prima facie evidence of the facts involved, the determination should not be given preclusive effect." Id. $\$ 29$ comment $c$.

96. Where the determination of an issue is ambivalent, see supra note 92 and accompanying text, precluding relitigation of the issue "would extend the effects of imperfections in the adjudicative process beyond the limits of the first adjudication, within which [the effects] are accepted only because of the practical necessity of achieving finality." RESTATEMENT, supra note $2, \S 29$ comment $g$.

97. The probability of successful invocation of issue preclusion may be assessed by evaluating the factors set out supra notes 91-95 and accompanying text. When future preclusion is unlikely, the court need not concern itself with exploitation of unrepresented third parties. 


\section{b. Breadth of Discretion}

To deter evasion of preclusion while giving maximum play to the autonomy of the participants, the trial court must have very broad discretion, subject to reversal only upon clear abuse. The decision whether to vacate depends on several factors peculiarly within the knowledge and competence of the trial judge. ${ }^{88}$ In addition, setting a lower standard of review introduces a systematic bias; because plaintiff and defendant unite in moving to vacate, only denials give rise to appeals. ${ }^{98}$

\section{c. Examples}

Two examples demonstrate the proposed exercise of discretion by a trial court faced with the possibility of settlement conditioned on vacatur. In the first example, the joint motion to vacate should be denied; in the second, vacatur should be granted to allow settlement.

Andy, the driver of a car, and Bob, his passenger, are involved in a collision with a car driven by Doug. Andy wins a substantial judgment against Doug for personal injuries similar to those suffered by Bob. ${ }^{100}$ Andy and Doug negotiate a settlement, conditioned on vacatur, which is slightly greater than Andy's expected value of the judgment on appeal. In the absence of other consideratons, the motion to vacate should be denied.

Xavier, an industrial worker, contracts a rare new disease called asbestosis. Although only one case involving asbestosis has ever come to trial, and the jury held for defendant Fibrebored, Xavier elects to initiate a products liability suit against his employer Jims-Manhole Corp. During the trial, thirty more cases of asbestosis among Jims-Manhole workers are diagnosed. Xavier wins a huge jury verdict on the theory that asbestos is an ultrahazardous substance, regardless of the design of the asbestos product. The judge regards this determination as questionable. Manhole negotiates a settlement conditioned on vacatur with Xavier and the thirty ill workers, who have just instituted suits in several courts. The trial court should vacate the judgment to give effect to the settlement agreement.

98. See supra notes 92 (ambivalence of determination), 93 (alternative bases), 94 (adequate incentive to litigate), and accompanying text. Also, the trial judge is uniquely able to assess the defendant's good faith in choosing trial over settlement. See text accompanying note 96.

99. Broad discretion does not, however, deprive the parties of their right to appeal. If the joint motion to vacate is granted, the settlement takes effect, and no appeal is necessary. If vacatur is denied, the judgment for plaintiff may be appealed by defendant, who fears future preclusive effects. See Nestle, 596 F. Supp. at 1448 ("Both parties have carefully preserved their rights to appeal and to continue to press their other claims if the judgment is not vacated.").

100. This hypothetical is based on Restatement, supra note $2, \S 29$ illustration 2. 


\section{GonClusion}

In the absence of compulsory joinder and consolidation, the doctrine of issue preclusion must impose upon the traditional adversary system judicial economy, consistency, finality of judgments, and legitimacy. A compromise doctrine, issue preclusion strikes a workable balance between public and private interests. The device of settlement conditioned on vacatur disturbs this balance by allowing the parties to a dispute to conspire against the interests of unrepresented future parties and the judicial system. In a party-initiated, party-controlled procedural regime, such a device has enormous potential for abuse. Appropriate standards of decision must be formulated immediately, not only to preserve important public interests and effective operation of issue preclusion, but also to ensure that potential litigants do not make distorted calculations.

Still, vacating an entered judgment to allow settlement serves public policy in some situations. To reach a sounder equilibrium fusing issue preclusion with the bipolar adversary system, vacatur must be prohibited in cases giving rise to the possibility of defensive issue preclusion, and left largely to trial court discretion in cases that form a basis for offensive preclusion. ${ }^{101}$

101. Because the initial trial court's discretion to vacate is keyed to the conditions governing relitigation in a second forum, this Note's solution to the problem of settlement conditioned on vacatur will change along with shifts in the doctrine of issue preclusion. 
